\title{
Lollipop Dosage Form
}

National Cancer Institute

\section{Source}

National Cancer Institute. Lollipop Dosage Form. NCI Thesaurus. Code C69068.

A solid composed of a sug ared, medicated candy mounted to a stick, which can be held while sucking or chewing on the candy. 